\title{
PENGEMBALIAN FUNGSI BAITUL MAL WA TAMWIL MELALUI STRATEGI PENYELESAIAN MASALAH RENTENIR DI TASIKMALAYA
}

\author{
Agus Ahmad Nasrulloh \\ Program Studi Ekonomi Syariah Universitas Siliwangi \\ Jl. Siliwangi No. 24 Kota Tasikmalaya \\ agusahmad@unsil.ac.id
}

\begin{abstract}
Abstrak
Penelitian ini bertujuan untuk menemukan masalah dan solusi dalam mengembalikan fungsi Baitul Mal Wa Tamwil melalui strategi penyelesaian masalah rentenir di Tasikmalaya. Metode yang digunakan yaitu metode kualitatif-kuantitatif dengan pendekatan analytic network process (ANP). Hasil penelitian menunjukkan bahwa masalah utama yang menghambat terlaksananya fungsi BMT yang diakibatkan oleh rentenir dari sisi masalah edukasi adalah "lemahnya edukasi mengenai riba (fiqh riba)", masalah ekonomi yaitu "kebutuhan hidup masyarakat yang mendesak", masalah lingkungan yaitu "sangat mudah mengakses rentenir" dan dari masalah regulasi yaitu "tidak ada ketegasan pemerintah terhadap rentenir". Sedangkan solusi terbaik untuk mengembalikan fungsi BMT melalui strategi penyelesaian rentenir terdiri dari solusi edukasi yaitu "sosialisasi oleh akademisi dan majelis ta"lim mengenai pentingnya BMT, fiqh riba", solusi ekonomi yaitu "bantuan dana bergulir dari pemerintah non bunga yang tidak berbelit-belit", solusi lingkungan yaitu "peran ketua RT dan RW untuk memberantas rentenir", dan solusi regulasi yaitu "ketegasan pemerintah dalam mengatasi maraknya rentenir termasuk sanksinya“.
\end{abstract}

Kata kunci: Baitul Mal Wa Tamwil, rentenir, analytic network process

\begin{abstract}
This study aims to find problems and solutions to restore the function of Baitul Mal Wa Tamwil through strategies to resolve moneylenders in Tasikmalaya. The method used is a qualitative-quantitative method with an analytic network process (ANP) approach. The results showed that the main problems that hampered the implementation of BMT functions caused by moneylenders in terms of educational problems were "weak education regarding usury (usury fiqh)", economic problems namely "urgent life necessities", environmental problems namely "very easy to access moneylenders" And from the regulatory problem namely "there is no firmness of the government towards moneylender". While the best solution to restore the function of BMT through the moneylender settlement strategy consists of an educational solution that is "socialization by academics and legislators regarding the importance of BMT, usury fiqh", economic solutions namely "convoluted non-interest government revolving fund assistance", the environmental solution is "the role of the $R T$ and $R W$ leaders to eradicate moneylenders", and a regulatory solution namely "the firmness of the government in overcoming the rampant moneylenders including sanctions".
\end{abstract}

Keywords: Baitul Mal Wa Tamwil, moneylender, analytic network process

Received: 2020-01-3 | Reviced: 2020-01-13 | Accepted: 2020-02-01

Indexed : Sinta 2, DOAJ, Garuda, Crossref, Google Scholar |DOI https://doi.org/10.29313/amwaluna.v4i1.5271 


\section{PENDAHULUAN}

A. Latar Belakang

Baitul Mal Watamwil (BMT) merupakan salah satu lembaga keuangan mikro syariah yang hadir untuk melayani para pelaku usaha mikro kecil menengah (UMKM) atau berpenghasilan rendah, yang tidak terlayani oleh lembaga keuangan besar seperti bank, karena dinilai tidak bankable. Hubungan antara masyarakat yang masuk ke dalam kelompok usaha mikro dan lembaga keuangan mikro tidak bisa dipisahkan, karena salah satu kendala atau masalah yang dihadapi oleh UMKM termasuk di negara Indonesia adalah masalah kurangnya permodalan untuk mengembangkan market share-nya, dan untuk mengatasi permasalahan tersebut maka UMKM harus bekerjasama dengan lembaga keuangan termasuk di dalamnya adalah lembaga keuangan mikro syariah seperti BMT.

Pembiayaan yang diberikan BMT diharapkan mampu mengatasi permasalahan UMKM diatas, akan tetapi proses pembiayaan yang diterapkan oleh BMT masih belum mampu ditempuh oleh seluruh UMKM, karena masih saja ada pelaku UMKM yang tidak bisa menempuh seluruh prosedur pembiayaan di BMT. Hal ini jelas mempersulit langkah UMKM untuk dapat mengembangkan usaha karena akses modal, dan UMKM tentunya tidak bisa diam begitu saja, mereka harus tetap mencari sumber modal yang dinilai sederhana.

Permasalahan UMKM ini dijadikan sasaran empuk bagi para penyedia jasa keuangan illegal dalam hal ini adalah rentenir. Mereka hadir dengan segala kemudahannya menyediakan jasa pembiayaan untuk modal atau konsumtif kepada masyarakat atau UMKM, prosedurnya singkat, tidak banyak persyaratan yang diminta, sehingga keberadaannya ini disambut dengan antusias oleh UMKM yang tidak bisa mendapatkan akses kepada BMT. Akan tetapi, dibalik segala kemudahan yang diberikan, kredit yang diberikan rentenir ini ternyata menyisakan banyak masalah. Dibalik kemudahan akses pinjaman yang diberikan, bunga kredit yang diberikan ternyata sangat besar. Tidak sedikit masyarakat yang kehilangan harta bendanya karena terjerat utang kepada rentenir. Ironisnya, meskipun hal ini terjadi, masih saja permintaan pinjaman kepada rentenir ini masih banyak diminati. Kebutuhan ekonomi yang mendesak, keterbatasan pengetahuan yang minim dari masyarakat membuat mereka tidak berfikir lama untuk mengajukan pinjaman kepada rentenir. 
Fenomena tentang maraknya rentenir, terjadi juga di daerah Kota Tasikmalaya Jawa Barat. Menurut Ir. Nanang Nurjamil, Pemerintah Kota Tasikmalaya melalui Dinas KUMKM PERINDAG dan BPMPPT harus segera melakukan penertiban. Tingginya angka kemiskinan di Kota Tasikmalaya, menurutnya bisa jadi disebabkan oleh maraknya praktek rentenir yang berkedok koperasi dan lembaga perkreditan rakyat, atau disinyalir banyak pihak yang secara sembunyi-sembunyi melakukan bunga pinjaman yang mencekik. Ketika masyarakat telat bayar, seringkali si penagih melakukan ancaman, padahal sudah jelas dalam pasal 368 ayat 1 Kitab Undang-Undang Hukum Pidana (KUHP) tentang larangan untuk melakukan pemaksaan dengan kekerasan atau ancaman kepada orang lain untuk memberikan sesuatu (Nanang Nurjamil, 2018).

Fakta lain yang mengenjutkan adalah, menurut H.M. Firmansyah selaku Kepala Dinas Koperasi, Usha Mikro Kecil Menengah, Perindustrian dan Perdagangan Kota Tasikmalaya mengungkapkan bahawa saat ini banyak usaha simpan pinjam uang (rentenir) berkedok koperasi. Dari 620 koperasi yang ada, hanya sekitar 225 yang aktif simpan pinjam. Pihaknya mengaku kesulitan memantau pergerakan usaha pinjaman uang di Kota Tasikmalaya. Terlebih biasanya pusatnya berada di luar kota (Firmansyah, 2019).

Alasan utama masyarakat terjerat hutang kepada rentenir adalah karena kebutuhan yang mendesak untuk mempertahankan keberlangsungan dagangnya, nominal pinjaman yang kecil, prosedur cepat dan tidak berbelit-belit, serta persyaratan yang mudah bahkan tidak perlu jaminan, itulah yang membuat para pedagang dan ibu rumah tangga lebih memilih pinjam uang ke rentenir, karena dipandang mudah dan praktis dibandingkan mengajukan pinjaman ke lembaga keuangan (Kabar Priangan, 2018).

Kondisi di atas sepintas masyarakat diawal sangat menguntungkan masyarakat, akan tetapi bunga yang tinggi tidak membuat pedagang berfikir lanjut untuk meminjam pada rentenir. Selain itu, maraknya rentenir ternyata membuat peran lembaga keuangan seperti Baitul Mal wa Tamwil (BMT) dalam menjalankan fungsi dan perannya sebagai mitra penyedia jasa pembiayaan untuk mendorong dan mengembangkan potensi serta kemampuan ekonomi anggota dan menjauhkan masyarakat dari praktik keuangan non Islam sedikit demi sedikit mulai berkurang. Hal ini dibenarkan oleh salah seorang Account Officer (AO) salah satu 
BMT di Tasikmalaya. Menurutnya juga, kondisi ini tidak bisa dibiarkan berlarutlarut, harus segera diselesaikan dengan mencari penyebab-penyebab utama mengapa hal ini terus terjadi kemudian dicarikan solusi strategis guna menyelesaikannya, dengan cara mensinergikan seluruh elemen yang terkait, seperti pemerintah daerah, pusat, akademisi, lembaga keuangan mikro (BMT) dan masyarakat itu sendiri untuk menyelesaikan permasalahan rentenir yang sudah menjamur dan menimbulkan keresahan dari masyarakat. Dengan diselesaikannya masalah rentenir, maka diharapkan fungsi dan peran BMT akan kembali ke semula, yaitu menjadi mitra usaha bagi UMKM dan sesuai aturan Islam.

Beberapa penelitian terkait dengan penyelesaian masalah rentenir guna mengembalikan fungsi BMT telah banyak dilakukan dan menjadi rujukan peneliti saat ini yaitu : Pertama, untuk mengurangi ketergantungan masyarakat terhadap rentenir adalah dengan strategi memberikan pinjaman tanpa bunga, tanpa jaminan dan tanpa potongan, diangsur dengan batas waktu maksimal 10 bulan oleh lembaga BAZNAS dengan infaq (Naning Nur Hidayah, 2018).

Kedua, menyebutkan bahwa ibuibu terjerat rentenir adalah karena kebutuhan modal usaha untuk berjualan. Solusi untuk menyelesaikannya adalah dengan membangun kesadaran bersama melalui pertemuan diskusi-diskusi kecil atau Focus Group Discussion secara intens. Perencanaan dan pelaksanaan programnya adalah bekerjasama dengan Lazismu untuk memberikan pinjaman tanpa bunga, dan membentuk kelompok usaha kecul menengah bernama "Pena Surya" untuk wadah simpan pinjaman dan keberlanjutan pemberdayaan ibu-ibu setelah terbebas dari belenggu rentenir (Ramadhan, 2017).

Ketiga, strategi yang diterapkan BMT untuk menyelamatkan masyarakat dari rentenir adalah inovasi produk, perekrutan anggota, layanan mudah dan nyaman, sosialisasi dan jemput bola. Selain itu, dalam analisis SWOT menyimpulkan bajwa adalah beberapa strategi yang bisa dilakukan BMT yaitu, peningkatan promosi pada media social, meningkatkan jaringan dengan para ulama/kiai dan lembaga terkait, melakukan diferensiasi dan inovasi produk dan evaluasi kinerja secara berkala (Mujaddidi, 2017).

Keempat, keberadaan koperasi (BMT), setidaknya mempunyai beberapa peran yakni sebagai berikut; pertama menjauhkan masyarakat dari praktik ekonomi non syariah. Kedua, melakukan 
pembinaan dan pendanaan usaha kecil. Ketiga, melepaskan ketergantungan pada rentenir. Keempat, menjaga keadilan ekonomi masyarakat dengan distribusi yang merata. Sedangkan faktor penentu yang mendorong pedagang kecil untuk meminjam kredit dari rentenir adalah faktor kepercayaam, faktor aksesibilitas dan faktor transaksi (Varghese, 2013).

Oleh karena itu, melalui penelitian ini akan dibuat suatu model yang akan menemukan permasalahan-permasalahan yang menghambat terlaksanananya fungsi BMT yang diakibatkan oleh rentenir di Tasikmalaya disertai dengan solusi-solusi terbaik guna mengembalikan fungsi BMT melalui strategi penyelesaian rentenir.

\section{B. Metode Penelitian}

Penelitian ini termasuk penelitian kualitatif-kuantitatif melalui metode Analytic Network Process (ANP). Maksud dari penelitian ini adalah menemukan permasalahan yang paling dominan yang menyebabkan terhambatnya terciptanya wirausaha kreatif berbasis syariah serta menemukan solusi terbaik agar wirausaha kreatif berbasis syariah tercipta dengan baik di Kota Tasikmalaya Jawa Barat Indonesia. Dengan metode ini maka data yang digunakan merupakan data primer yang didapat dari hasil wawancara (indepth interview) dengan para expert mengenai permasalahan yang sedang diteliti, dilanjutkan dengan pengisian kuesioner untuk melakukan penilaian mengenai jawaban yang paling dominan.

Pemilihan responden pada penelitian ini dilakukan dengan mempertimbangkan pemahaman responden tersebut terhadap permasalahan yang sedang diteliti yaitu mengenai kewirausahaan di Kota Tasikmalaya. Jumlah responden dalam penelitian ini terdiri dari tujuh orang, dengan pertimbangan bahwa mereka cukup berkompeten dalam mewakili keseluruhan populasi. Dalam analisis ANP jumlah sampel/responden tidak digunakan sebagai patokan validitas. Syarat responden yang valid dalam ANP adalah bahwa mereka adalah orang-orang yang expert di bidangnya. Oleh karena itu, responden yang dipilih dalam survey ini adalah para pakar/peneliti, akademisi, regulasi, praktisi/profesional, yang mengetahui keadaan perekonomian khususnya kewirausahaan di Kota Tasikmalaya.

Pertanyaan dalam kuesioner ANP berupa pairwise comparison (pembandingan pasangan) antar elemen dalam cluster untuk mengetahui mana di antara keduanya yang lebih besar pengaruhnya (lebih dominan) dan seberapa besar perbedaannya dilihat dari satu sisi. Skala numerik 1-9 yang digunakan 
Agus Ahmad Nasrulloh, Pengembalian Fungsi Baitul Mal Wa Tamwil Melalui Strategi ....

merupakan terjemahan dari penilaian verbal.

Pengisian kuesioner oleh responden harus didampingi peneliti untuk menjaga konsistensi dari jawaban yang diberikan. Pada umumnya, pertanyaan pada kuesioner ANP sangat banyak jumlahnya. Sehingga faktor-faktor non teknis dapat menyebabkan tingginya tingkat inkonsistensi.

Tabel 1: Perbandingan Skala Verbal dan Skala Numerik

\begin{tabular}{|c|c|}
\hline SKALA VERBAL & $\begin{array}{c}\text { SKALA } \\
\text { NUMERIK }\end{array}$ \\
\hline $\begin{array}{c}\text { Amat sangat lebih } \\
\text { besar pengaruhnya }\end{array}$ & 9 \\
\hline $\begin{array}{c}\text { Sangat lebih besar } \\
\text { pengaruhnya }\end{array}$ & 7 \\
\hline Lebih besar \\
pengaruhnya & 6 \\
\hline $\begin{array}{c}\text { Sedikit lebih besar } \\
\text { pengaruhnya }\end{array}$ & 3 \\
\hline & 2 \\
\hline $\begin{array}{c}\text { Sama besar } \\
\text { pengaruhnya }\end{array}$ & 1 \\
\hline Sumber: Ascarya (2005)
\end{tabular}

Sumber: Ascarya (2005)

\section{Tahapan Penelitian}

Berikut adalah tahapan penelitian dengan metode ANP:

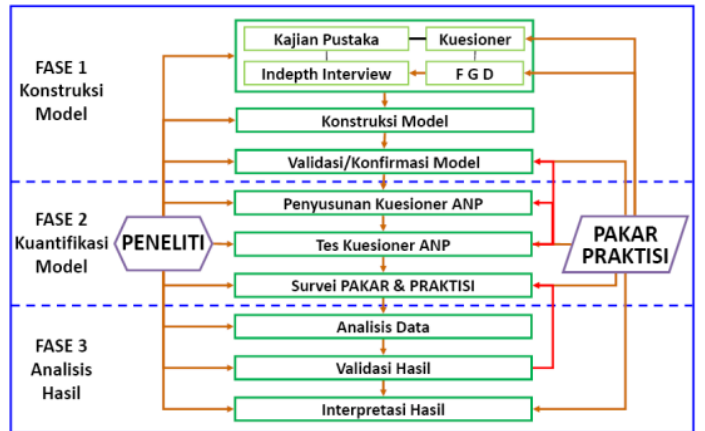

Sumber: Ascarya dan Yumanita (2010)

\section{Gambar 1: Tahapan Penelitian}

\section{Teknik Analisis Data}

Pertama, Geometric Mean. Untuk mengetahui hasil penilaian individu dari para responden dan menentukan hasil pendapat pada satu kelompok dilakukan penilaian dengan menghitung geometric mean (Saaty dan Vargas, 2006). Pertanyaan berupa perbandingan (Pairwise comparison) dari responden akan dikombinasikan sehingga membentuk suatu konsensus. Geometric mean merupakan jenis penghitungan rata-rata yang menunjukan tendensi atau nilai tertentu dimana memiliki formula sebagai berikut (Ascarya, 2011):

$$
\left(\prod_{i}^{n}=1 a_{i}\right)^{1 / n}=\sqrt[n]{a_{1}} a_{2 . .} a_{n}
$$

Kedua, Rater Agreement. Rater agreement adalah ukuran yang menunjukkan tingkat kesesuaian (persetujuan) para responden (R1-Rn) terhadap suatu masalah dalam satu cluster. Adapun alat yang digunakan untuk 
mengukur rater agreement adalah Kendall's Coefficient of Concordance $(\mathrm{W} ; 0<\mathrm{W} \leq 1) . \quad \mathrm{W}=1$ menunjukan kesesuaian yang sempurna (Ascarya, 2011).

Untuk menghitung Kendall's (W), yang pertama adalah dengan memberikan ranking pada setiap jawaban kemudian menjumlahkannya.

$$
R_{i}=\sum_{j}^{m}=1 r_{i, j}
$$

Nilai rata-rata dari total ranking adalah:

$R=\frac{1}{2} m(n+1)$

Jumlah kuadrat deviasi (S), dihitung dengan formula:

$S=\sum_{i}^{n}=1\left(R_{i}-\bar{R}\right)^{2}$

Sehingga diperoleh Kendall's W, yaitu:

$$
W=\frac{12 S}{m^{2}\left(n^{3}-n\right)}
$$

Jika nilai pengujian $\mathrm{W}$ sebesar 1 $(\mathrm{W}=1)$, dapat disimpulkan bahwa penilaian atau pendapat dari para responden memiliki kesesuaian yang sempurna. Sedangkan ketika nilai $\mathrm{W}$ sebesar 0 atau semakin mendekati 0 , maka menunjukan adanya ketidaksesuaian antar jawaban responden atau jawaban bervariatif (Ascarya, 2011).

\section{PEMBAHASAN}

\section{A. Literature Review}

Baitul Maal Wat Tamwil (BMT)

adalah balai usaha mandiri terpadu yang isinya berintikan bayt al-mal wa al-tamwil dengan kegiatan mengembangkan usahausaha produktif dan investasi dalam meningkatkan kualitas kegiatan ekonomi pengusaha kecil ke bawah dan kecil dengan antara lain mendorong kegiatan menabung dan menunjang pembiayaan kegiatan ekonominya. Baitul Maal Wat Tamwil juga bisa menerima titipan zakat, infak, dan sedekah, serta menyalurkannya sesuai dengan peraturan dan amanatnya. Selain itu, yang mendasar adalah bahwa seluruh aktivitas BMT harus dijalankan berdasarkan prinsip muamalah ekonomi dalam Islam. Baitul Mal Wat Tamwil (BMT) adalah balai usaha mandiri terpadu yang isinya berintikan bayt al-mal wa attamwil dengan kegiatan mengembangkan usaha-usaha produktif dan investasi dalam meningkatkan kualitas kegiatan ekonomi pengusaha kecil bawah dan kecil dengan mendorong kegiatan menabung dan menunjang pembiayaan kegiatan ekonominya (Ridwan, 2013).

Dengan demikian, keberadaan BMT dapat dipandang memiliki dua fungsi utama yaitu sebagai media penyalur pendayagunaan harta ibadah seperti zakat, infak, sedekah dan wakaf, serta dapat pula berfungsi sebagai institusi yang bergerak dibidang investasi yang bersifat produktif sebagaimana layaknya bank. Pada fungsi kedua ini dapat dipahami bahwa selain Online ISSN : 2540-8402 | Print ISSN : 2540-8399 
Agus Ahmad Nasrulloh, Pengembalian Fungsi Baitul Mal Wa Tamwil Melalui Strategi ....

berfungsi sebagai lembaga keuangan, BMT juga berfungsi sebagai lembaga ekonomi. Sebagaimana lembaga keuangan (Soemitra, 2014).

Fungsi Baitul Mal Wat Tamwil (BMT), yaitu: pertama, mengidentifikasi, memobilisasi, mengorganisir, mendorong dan mengembangkan potensi serta kemampuan ekonomi anggota, kelompok, usaha anggota muamalat (pokusma) dan kerjanya; Kedua, Mempertinggi kualitas SDM anggota dan Pokusma menjadi lebih profesional dan islami sehingga makin utuh dan tangguh menghadapi tantangan global; Ketiga, Menggalang dan mengorganisir potensi masyarakat dalam rangka meningkatkan kesejahteraan anggota (Soemitra, 2010).

Selain itu BMT juga memiliki beberapa peran, diantaranya adalah: pertama: Menjauhkan masyarakat dari praktik ekonomi yang bersifat non islam melakukan sosialisasi di tengah masyarakat tentang arti penting sistem ekonomi islam. Hal ini bisa dilakukan dengan pelatihan-pelatihan mengenai caracara bertransaksi yang islami. Misalnya ada bukti dalam bertransaksi, dilarang curang dalam menimbang barang, jujur terhadap konsumen, dan sebagainya;

Kedua: Melakukan pembinaan dan pendanaan usaha kecil. BMT harus harus bersikap aktif menjalankan fungsi sebagai lembaga keuangan mikro, misalnya dengan jalan pendampingan, pembinaan, penyuluhan, dan pengawasan terhadap usaha-usaha nasabah;

$$
\text { Ketiga: Melepaskan }
$$

ketergantungan pada rentenir, masyarakat yang masih tergantung rentenir disebabkan rentenir mampu memenuhi keinginan masyarakat dalam memenuhi dana dengan segera. Maka BMT harus mampu melayani masyarakat lebih baik, misalnya selalu tersedia dana setiap saat, birokrasi yang sederhana dan lain sebagainya.

Keempat : Menjaga keadilan ekonomi masyarakat dengan distribusi yang merata. Fungsi BMT langsung berhadapan dengan masyarakat yang kompleks dituntut harus pandai bersikap, oleh karena itu langkah-langkah untuk melakukan evaluasi dalam rangka pemetaan skala prioritas yang harus diperhatikan, misalnya dalam masalah pembiayaan, BMT harus memperhatikan kelayakan usaha dalam hal golongan nasabah dan juga jenis pembiayaan yang dilakukan (Huda \& Haykal).

\section{B. Hasil Penelitian}

Dekomposisi dibuat setelah dilakukan penelitian lapangan melalui indepth interview kepada para responden mengenai permasalahan penyelesaian rentenir untuk mengembalikan fungsi BMT di Tasikmalaya. Atas hasil penelitian 
yang telah dilakukan maka diketahui terdapat beberapa masalah yang ada pada masyarakat yang terjerat oleh rentenir Tasikmalaya yang dapat menghambat BMT dalam menjalankan fungsinya.. Penulis membagi menjadi dua kategori masalah yaitu masalah dan solusi. Berikut adalah masalah yang terjadi yang dapat menghambat BMT dalam menjalankan fungsinya dengan strategi penyelesaian rentenir di Tasikmalaya:

Pertama, Masalah Regulasi. Diantara masalah regulasi yang ada yaitu: 1) Regulasi/ payung hukum BMT tidak terlalu spesifik seperti perbankan; 2) Tidak ada ketegasan pemerintah terhadap rentenir; 3) Lemahnya penerapan sanksi mengenai masyarakat yang melakukan penghimpunan dana dari masyarakat karena sulitnya melakukan identifikasi kasusu yang harus menunggu laporan dari masyarakat.

Kedua, Masalah Edukasi. Diantara masalah edukasi yang ada yaitu: 1) Lemahnya edukasi mengenai riba (fiqh riba); 2) Minimnya peran serta lembaga pendidikan dalam melakukan edukasi mengenai lembaga mikro kepada masyarakat; 3) Lemahnya pendidikan formal masyarakat terutama mengenai manajemen keuangan (usaha dan ekonomi rumah tangga)
Ketiga,Masalah Ekonomi. Diantara masalah ekonomi yang ada yaitu: 1) Kebutuhan hidup masyarakat yang mendesak; 2) Ketersediaan dana di BMT tidak cukup; 3) Masalah kebijakan ekonomi pemerintah yang tidak pro rakyat kecil; 4) Produk BMT yang kurang inovatif

Keempat, Masalah Lingkungan. Diantara masalah lingkungan yang ada yaitu: 1) Ketertarikan/ ikut-ikutan dengan lingkungan sekitar (pengaruh tetangga); 2) Sangat mudah mengakses rentenir; 3) Tidak ada sumber informasi mengenai BMT; 4) Kantor BMT biasanya kecil bahkan tidak dikenal masyarakat.

Dari rangkaian masalah diatas, maka selanjutnya penulispun menawarkan solusi yang terbaik untuk mengembalikan fungsi BMT melalui strategi penyelesaian rentenir di Tasikmalaya hasil indepth interview kepada para responden pakar. Solusi yang ditawarkan dibagi menjadi empat bagian.

Pertama, Solusi Regulasi. Diantara solusi regulasi yaitu: 1) Dibutuhkan regulasi yang lebih khusus mengenai BMT seperti perbankan; 2) Ketegasan pemerintah dalam mengatasi maraknya rentenir termasuk sanksinya; 3) Pemerintah desa/ kelurahan membuat aturan mengenai larangan rentenir. 
Agus Ahmad Nasrulloh, Pengembalian Fungsi Baitul Mal Wa Tamwil Melalui Strategi ....

Kedua, Solusi Edukasi. Diantatar solusi edukasi yaitu: 1) Sosialisasi oleh akademisi dan majelis ta'lim mengenai pentingnya BMT, fiqh riba; 2) Adanya pelatihan manajemen usaha dan ekonomi rumah tangga pada masyarakat; 3) Adanya pusat pendidikan, konsultasi usaha mikro bagi UKM/UMKM : pengelolaan keuangan.

Ketiga, Solusi Ekonomi. Dinatara solusi ekonomi yaitu: 1) Bantuan dana bergulir dari pemerintah non bunga yang tidak berbelit-belit; 2) Kebijakan Ekonomi pemerintah yang berpihak pada masyarakat kecil; 3) Kerjasama usaha dengan pihak yang telah sukses; 4) Produk BMT lebih bervariasi mengikuti kebutuhan pasar, dengan tingkat margin/ bagi hasil yang bersaing.

Keempat, Solusi Lingkungan. Diantara solusi lingkungan yaitu: 1) Peran serta ketua RT dan RW untuk memberantas rentenir; 2) Perbanyak program pengabdian pada masyarakat dari akademisi terkait kesadaran lingkungan mengenai bahaya riba; 3) Menciptakan/ rekayasa lingkungan Islami.

Dari uraian di atas maka model jaringan ANP dalam rangka mengembalikan fungsi BMT melalui strategi penyelesaian rentenir di Tasikmalaya dapat dilihat pada gambar 2 . 


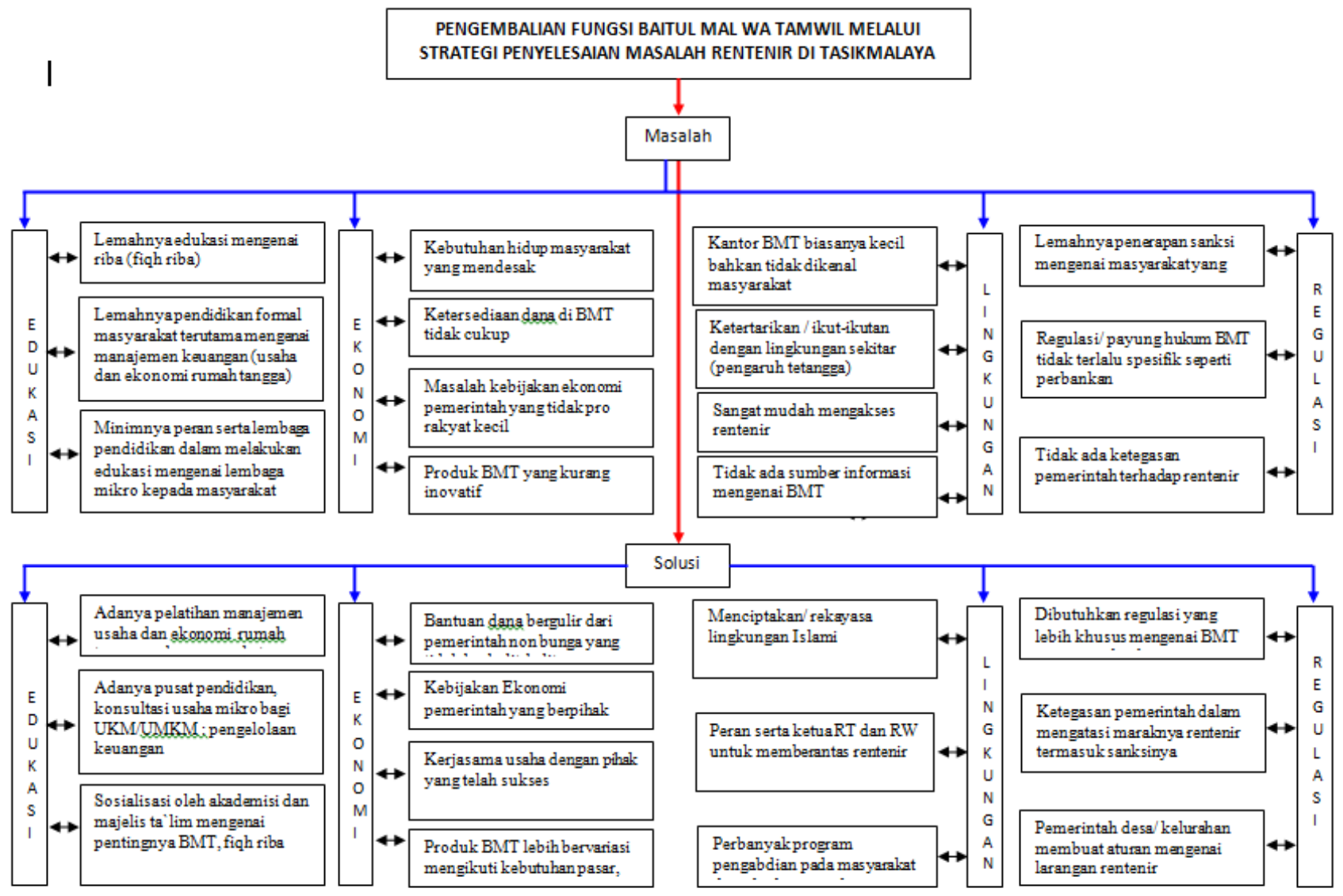

Gambar 2: Model Jaringan ANP 
Agus Ahmad Nasrulloh, Pengembalian Fungsi Baitul Mal Wa Tamwil Melalui Strategi ....

Dari model jaringan yang telah dibuat pada gambar 3, maka langkah selanjutnya yaitu membuat kuesioner dan menyebarkannya kepada para responden pakar untuk dicari jawaban yang paling menjadi prioritas atas permasalahan yang sedang diteliti.

Berdasarkan hasil analisis menggunakan software super decision berdasarkan konsensus dari para responden pakar maka diketahui urutan masalah edukasi yang paling dominan pada kategori masalah digambarkan pada gambar 3:

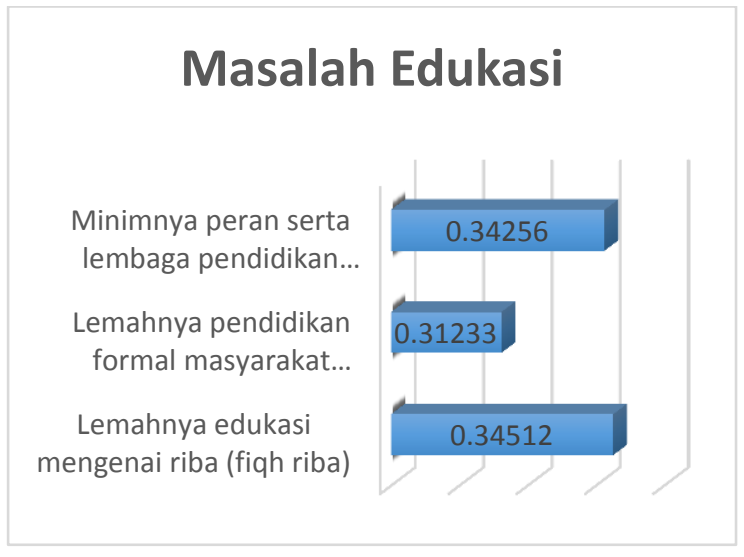

Gambar 3. Masalah Edukasi

Dari gambar 3, maka dapat diketahui bahwa dari sudut pandang masalah edukasi yang paling dominan dalam masalah rentenir yang menghambat peran BMT di Tasikmalaya yaitu “ lemahnya edukasi mengenai riba (fiqh riba)". Hal ini terjadi karena masyarakat belum mengetahui aturan dalam agama Islam tentang larangan riba, sehingga banyak masyarakat yang masih terlibat dengan rentenir manakala mereka membutuhkan dana untuk kebutuhan baik konsumtif maupun modal kerja. Urutan kedua yang paling dominan yaitu "minimnya peran serta lembaga pendidikan dalam melakukan edukasi mengenai lembaga keuangan mikro kepada masyarakat”. Realita di lapangan, para akademisi yang kompeten secara keilmuan di bidang ekonomi syariah kurang memberikan kontribusi kepada masyarakat dalam hal mengedukasi tentang adanya lembaga keuangan mikro yang berbasis syaiah khususnya yang dapat dimanfaatkan oleh masyarakat ketika membutuhkan dana. Selanjutnya urutan ketiga yaitu "lemahnya pendidikan formal masyarakat terutama mengenai manajemen keuangan (usaha dan ekonomi rumah tangga). Jika masyarakat lemah dalam pengetahuan manajemen keuangan, maka tidak akan mempertimbangkan dampak pinjaman modal dari rentenir yang akan mengganggu keberlangsungan usaha dikarenakan beban bunga yang berat. Nilai rater agreement yaitu sebesar $\mathrm{W}=0,603$ atau $60,3 \%$ yang artinya menunjukkan kesepakatan yang tinggi diantara rsponden dalam menjawab masalah edukasi.

Selanjutnya adalah masalah ekonomi. Dari gambar 4 dapat diketahui bahwa dari sudut pandang masalah edukasi yang paling dominan dalam masalah 
rentenir yang menghambat peran BMT di Tasikmalaya yaitu "kebutuhan hidup masyarakat yang mendesak". Kebutuhan masyarakat akan dana untuk memenuhi kebutuhannya baik konsumtif maupun produktif sering datang pada waktu-waktu yang diluar dugaan dan harus segera dipenuhi. Tidak memungkinkan mengajukan pembiayaan ke lembaga keuangan seperti BMT, karena butuh waktu untuk proses pembiayaan, sedangkan kebutuhan tersebut harus segera dipenuhi dan terkadang jumlahnya pun tidak terlalu besar. Masalah ekonomi kedua adalah "ketersediaan dana di BMT tidak cukup”. Kekurangan likuiditas yang dialami BMT mengakibatkan lembaga ini tidak bisa melayani pembiayaan yang diajukan oleh masyarakat, sehingga dengan terpaksa masyarakat harus mencari penyedia jasa pinjaman dana yang cepat seperti rentenir. Posisi yang ketiga yaitu "masalah kebijakan ekonomi pemerintah yang tidak pro rakyat kecil”. Pemerintah sebagai pemangku kebijakan dapat mengeluarkan kebijakan-kebijakan untuk menjaga stabilitas bahkan agar perekonomian dapat tumbuh. Akan tetapi terkadang kebijakan ini justru tidak berdampak positif pada rakyat kecil, yang menyebabkan kondisi perekonomian masyarakat golongan bawah semakin berat. Contohnya kebijakan fiscal seperti pajak dan subsidi. Terakhir dari masalah ekonomi yaitu "produk BMT yang kurang inovatif”'. Beragamnya jenis kebutuhan masyarakat tidak diikuti oleh inovasiinovasi produk yang ditawarkan BMT. Masyarakat menilai produk BMT terlalu kaku oleh aturan, sehingga mereka lebih memilih rentenir tatkala membutuhkan dana. Nilai rater agreement yaitu sebesar $\mathrm{W}=0,709$ atau $70,9 \%$ yang artinya menunjukkan kesepakatan yang tinggi diantara responden dalam menjawab masalah ekonomi.

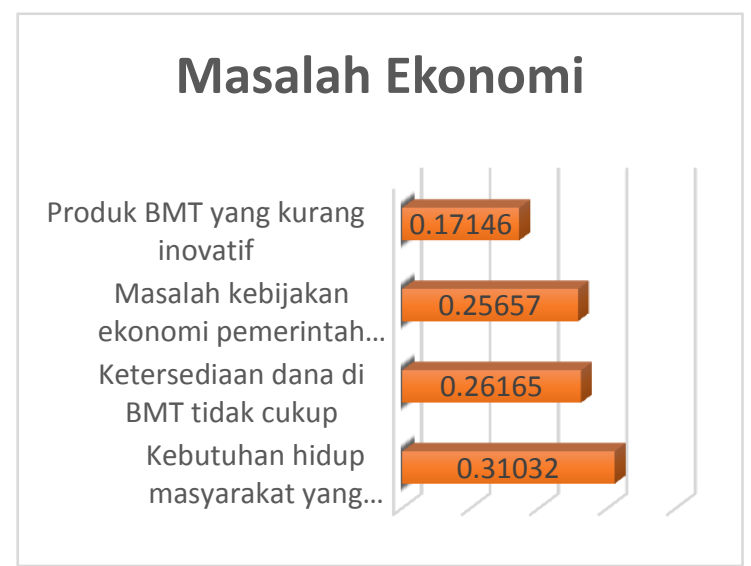

\section{Gambar 4: Masalah Ekonomi}

Masalah yang ketiga adalah masalah lingkungan. Pada gambar 5 dapat dilihat bahwa dari sudut pandang masalah lingkungan yang paling dominan dalam masalah rentenir yang menghambat peran BMT di Tasikmalaya yaitu "sangat mudah mengakses rentenir". Para pelaku rentenir yang menyediakan pinjaman dana mudah sekali diakses oleh masyarakat, tanpa perlu mendatangi mereka dimana mereka berada, akan tetapi justru renternirlah yang akan mendatangi masyarakat. Kemudahan 
Agus Ahmad Nasrulloh, Pengembalian Fungsi Baitul Mal Wa Tamwil Melalui Strategi ....

ini menjadi alasan yang paling kuat masyarakat lebih memilih rentenir manakala membutuhkan dana yang cepat dan tidak banyak persyaratan asalkan masyarakat siap dengan bunga pinjaman yang ditentukan. Masalah kedua yang paling dominan dari masalah lingkungan adalah "tidak ada sumber informasi mengenai BMT'. Minimnya informasi yang diterima masyarakat tentang keberadaan informasi membuat keberadaan BMT tidak dapat diketahui oleh masyarakat. Hal ini juga menjadi penyebab masyarakat menjadi kebingungan manakala membutuhkan akses pembiayaan kepada lembaga keuangan mikro yang formal dan sesuai prinsip syariah seperti BMT. Urutan ketiga dari masalah lingkungan yaitu "kantor BMT biasanya kecil bahkan tidak dikenal masyarakat”. Ukuran kantor yang tidak besar menjadikan BMT tidak dikenal oleh masyarakat. Physical evidence yang kurang baik ini membuat BMT kurang diminati oleh masyarakat bahkan tidak dikenal keberadaannya, padahal ini adalah hal yang penting untuk menumbuhkan rasa kepercayaan dan kepuasan konsumen terhadap BMT. Terakhir yang menjadi faktor dominan dalam masalah lingkungan adalah "ketertarikan atau ikut-ikutan dengan lingkungan sekitar (pengaruh tetangga)”. Kuatnya faktor lingkungan seperti tetangga bisa menjadi penyebab masyarakat harus berurusan dengan rentenir, hal ini bisa terjadi karena salah memilih pergaulan dengan tetangga. Nilai rater agreement yaitu sebesar $\mathrm{W}=0,709$ atau $70,9 \%$ yang artinya menunjukkan kesepakatan yang tinggi diantara responden dalam menjawab masalah lingkungan.

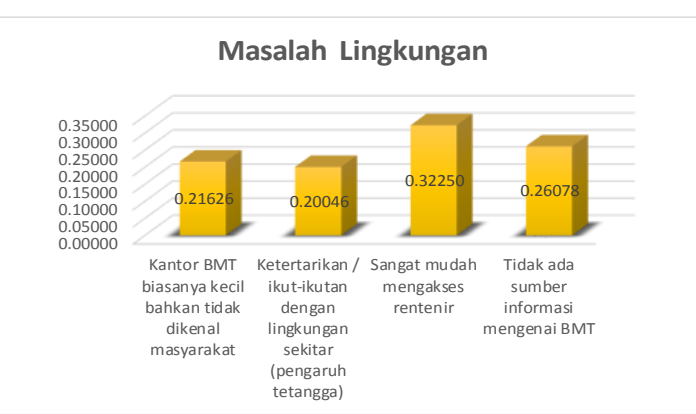

Gambar 5. Masalah Lingkungan

Masalah terakhir yang menyebabkan maraknya rentenir yang mengakibatkan berkurangnya fungsi BMT di Tasikmalaya adalah masalah regulasi. Yang paling dominan dari masalah regulasi adalah "tidak ada ketegasan pemerintah terhadap renternir". Pelaku rentenir bebas melakukan kegiatannya meskipun melanggar aturan. Itu semua terjadi karena tidak ada ketegasan bagi para pelaku rentenir. secara leluasa rentenir masuk dari satu daerah ke daerah yang lain mencari masyarakat yang sedang membutuhkan dana pinjamna dengan bunga yang besar dan rentenir tidak segansegan mengambil tindakan seperti menyita jaminan manakalah masyarakat tidak 
mampu membayar hutangnya. Masalah regulasi yang kedua adalah "lemahnya penerapan sanksi mengenai masyarakat yang melakukan penghimpunan dana dari masyarakat karena sulitnya melakukan identifikasi kasus yang harus menunggu laporan dari masyarakat". Maksud dari masalah ini adalah, masyarakat di suatu daerah kurang memiliki rasa peduli terhadap maraknya praktek rentenir yang meresahkan sebagian masyarakat lain yang terjerat rentenir, sehingga seolah-olah tidak terjadi apa-apa di tengah-tengah masyarakat. Kondisi ini menyulitkan para penegak hukum memberikan sanksi kepada para pelaku rentenir. masalah regulasi terakhir adalah "regulasi/ payung hukum BMT tidak terlalu spesifik seperti perbankan". Aktivitas perekonomian masyarakat pada sektor menengah kebawah cukup pesat, sehingga disini sebetulnya peran BMT sangat diperlukan. Akan tetapi karena keterbatasan yang dimiliki BMT terkait payung hukum, maka BMT ini tidak bisa menyelesaikan seluruh masalah yang dihadapi termasuk didalamnya penyelesaian pembiayaan bermasalah. Lain halnya dengan perbankan, aturannya lebih lengkap. Nilai rater agreement yaitu sebesar $\mathrm{W}=0,611$ atau $61,1 \%$ yang artinya menunjukkan kesepakatan yang tinggi diantara responden dalam menjawab masalah regulasi.

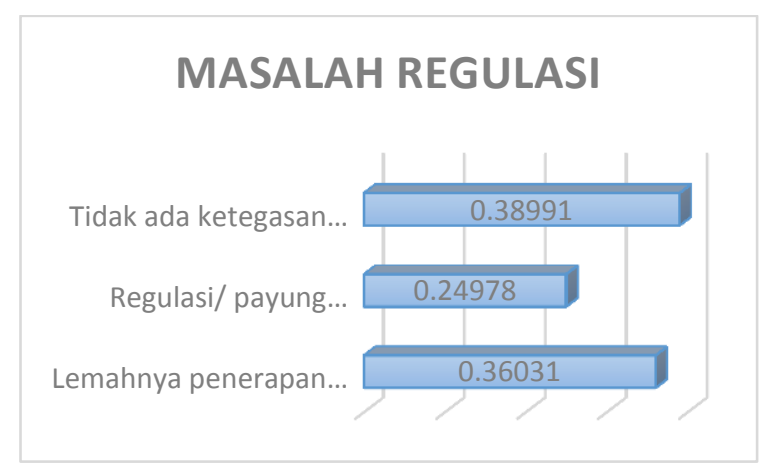

\section{Gambar 6. Masalah Regulasi}

Setelah mengetahui permasalahan, maka diketahui pula solusi-solusi dalam rangka mengembalikan fungsi BMT melalui strataegi penyelesaian rentenir di Tasikmalaya. Solusi pertama adalah solusi edukasi. Adapun urutan dari solusi edukasi dapat dilihat pada gambar 7 :

\section{SOLUSI EDUKASI}

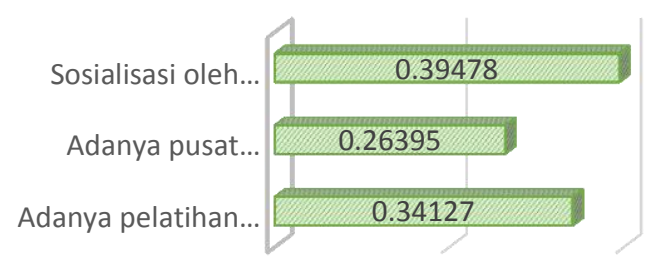

\section{Gambar 7. Solusi Edukasi}

Dari gambar 7 dapat diketahui solusi edukasi yang paling dominan yaitu "sosialisasi oleh akademisi dan majelis ta`lim mengenai pentingnya BMT, figh riba”. Akademisi seperti dosen harus melakukan kegiatan pengabdian kepada masyarakat untuk memberikan edukasi mengenai BMT mulai dari fungsi, peran dan tujuan kehadirannya bahkan 
Agus Ahmad Nasrulloh, Pengembalian Fungsi Baitul Mal Wa Tamwil Melalui Strategi ....

menunjukkan keberadaan kantor-kantor BMT. Dalam pelaksanaannya bisa bekerjasama dengan BMT-BMT yang ada di Tasikmalaya. Selain itu, peran ‘alim ulama atau ustad pun diperlukan terkait solusi edukasi. Tema-tema ceramah di pengajian atau pada khutbah jum at bisa mengangkat tema tentang fiqh riba. Dengan demikian, masyarakat akan memiliki literasi yang cukup mengenai BMT dan fiqh riba, sehingga manakala mereka dihadapkan dengan kebutuhan dana, maka akan menghubungi BMT meskipun akses ke rentenir mudah. Solusi kedua adalah "adanya pelatihan manajemen usaha dan ekonomi rumah tangga pada masyarakat”. Kegagalan dalam mengelola usaha dan keuangan membuat masyarakat terus mengalami kerugian dalam menjalankan usahanya. Salah satu penyebab dari kondisi ini adalah bercampurnya keuangan usaha dengan kelauarga yang mengakibatkan modal usaha tergerus, sehingga harus terus menambah modalnya dan jalan pintas yang mereka lakukan adalah melalui rentenir. Oleh karena itu pelatihan menajamen usaha termasuk manajemena keuangan keluarga menjadi salah satu solusi dominan yang memungkinan dilakukan untuk mengatasi kondisi tersebut, sehingga usaha yang dijalankan akan terus berkembang bahkan maju karena mampu mengelolanya dengan baik. Solusi terakhir adalah "adanya pusat pendidikan, konsultasi usaha mikro bagi UKM/UMKM:pengelolaan keuangan”. Artinya, setelah diberikan pelatihan manajemen usaha, maka perlu dilakukan pendampingan, agar pelaku usaha dengan mudah berkonsultasi manakala mengalami suatu masalah karena dapat diatasi sedini mungkin. Nilai rater agreement yaitu sebesar $\mathrm{W}=0,611$ atau $61,1 \%$ yang artinya menunjukkan kesepakatan yang tinggi diantara responden dalam menjawab solusi edukasi.

Solusi yang kedua adalah solusi ekonomi. Terdapat empat solusi ekonomi yang paling dominan sebagaimana terdapat pada gambar 8 , dan yang paling dominan dari keempat solusi tersebut menurut responden adalah "bantuan dana bergulir dari pemerintah non bunga yang tidak berbelit-belit”. Bantuan yang bersifat produktif bagi kemajuan ekonomi masyarakat bawah diharapkan dapat menjadi solusi untuk keberlangsungan usaha, disertai dengan pendampingan yang lebih baik karena bantuan ini untuk menaikkan kondisi perekonomian masyarakat bawah. Dengan adanya pendampingan yang lebih ketat, non bunga serta prosedur yang lebih simpel, maka bantuan ini akan terus bergulir bagi masyarakat yang lainnya. Solusi ekonomi 
kedua adalah "kebijakan ekonomi pemerintah yang berpihak pada masyarakat kecil". Solusi ini berkaitan dengan kebijakan-kebijakan fiskal seperti pajak dan subsidi. Kebijakan pajak yang dikeluarkan pemerintah selain memberikan efek positif pada perekonomian secara nasional, akan tetapi berdampak negatif pada masyarakat bawah, karena dengan kebijakan pajak yang dinaikkan maka kebutuhan hidup masyarakat menjadi tidak dapat terpenuhi karena tidak diimbangi oleh pendapatan yang meningkat. Selain itu subsidi harus lebih diprioritaskan bagi masyarakat bawah, demi mengurangi beban hidup masyarakat. Solusi ketiga adalah "kerjasama usaha dengan pihak yang telah sukses”. Para pelaku usaha kecil dan mikro serta berpenghasilan rendah, harus melakukan studi banding bahkan bekerja sama dengan pelaku usaha yang sudah sukses, agar bisa mempelajari di bidang produksi maupun pemasaran. Solusi terahir adalah "produk BMT lebih bervariasi mengikuti kebutuhan pasar dengan tingkat margin/ bagi hasil yang kompetitif". Kebutuhan masyarakat yang beragam tidak bisa diberikan skema pembiayaan yang sama, perlu disiapkan pola pembiayaan yang bersifat kondisional menyesuaikan kebutuhan pasar yang margin dan bagi hasilnya lebih menarik atau ringan. Nilai rater agreement yaitu sebesar $\mathrm{W}=0,706$ atau 70,6\% yang artinya menunjukkan kesepakatan yang tinggi diantara responden dalam menjawab solusi ekonomi.

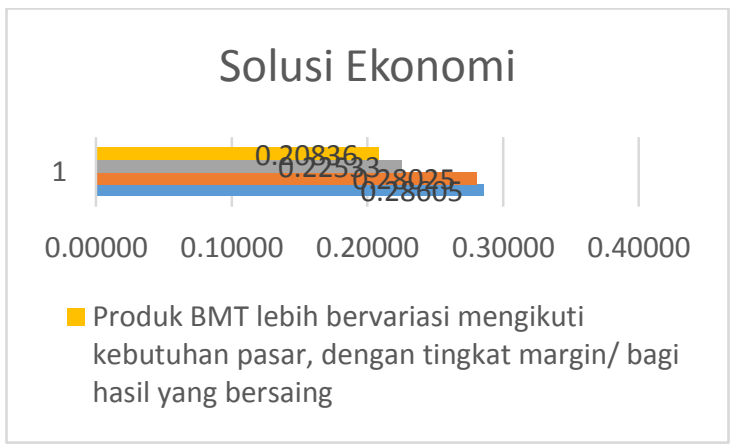

\section{Gambar 8. Solusi Ekonomi}

Solusi berikutnya untuk mengembalikan fungsi BMT melalui strategi penyelesaian rentenir di Tasikmalaya adalah solusi lingkungan, dapat dilihat pada gambar 9 di bawah ini:

\section{Solusi Lingkungan}

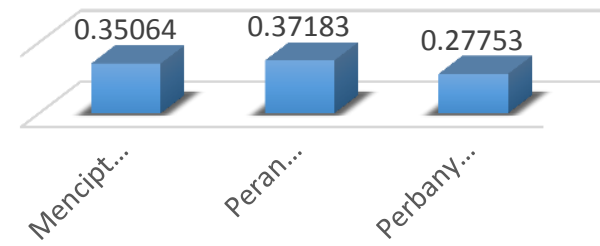

\section{Gambar 9. Solusi Lingkungan}

Solusi yang paling dominan menurut responden adalah "peran ketua $R T$ dan RW untuk memberantas rentenir". Aparatur pemerintah ini yang langsung tahu kondisi di lapangan, sehingga yang paling memungkinkan berperan langsung menyelesaikan permasalahan rentenir, mulai dari memberikan himbauan secara lisan maupun tulisan kepada masyarakat 
Agus Ahmad Nasrulloh, Pengembalian Fungsi Baitul Mal Wa Tamwil Melalui Strategi ....

untuk menghindari rentenir, bahkan memikirkan solusinya ketika masyarakat tidak menggunakan jasa rentenir ketika sedang membutuhkan dana. Selain itu, mengajak seluruh warga untuk bersamasama "memerangi" rentenir supaya tidak masuk ke lingkungan masyarakat. Solusi kedua yang dominan adalah "menciptakan/ rekayasa lingkungan Islami”. Upaya untuk membangun lingkungan yang Islami dapat dilakukan dengan cara menumbuhkan kegiatankegiatan keislaman ataupun memanfaatkan potensi yang telah hadir di masyarakat. Interaksi antar masyarakat dengan tetangga harus secara Islami, penyelesaian konflik, musyawarah mufakat yang sesuai dengan aturan Islam senantiasa diterapkan. Solusi ketiga dari solusi lingkungan adalah "Perbanyak program pengabdian kepada masyarakat dari akademisi terkait kesadaran lingkungan mengenai bahaya riba”. Para akademisi seperti dosen menyampaikan materi-materi tentang fiqh riba dalam kegiatan pengabdian masyarakat, sehingga literasi masyarakat menjadi bertambah dan ada perubahan ke arah yang lebih baik. Nilai rater agreement yaitu sebesar $\mathrm{W}=0,601$ atau $60,1 \%$ yang artinya menunjukkan kesepakatan yang tinggi diantara responden dalam menjawab solusi lingkungan.
Solusi terakhir untuk mengembalikan fungsi BMT melalui strategi penyelesaian rentenir di Tasikmalaya adalah solusi regulasi. Berikut dibawah ini adalah gambar urutan dari solusi regulasi yang paling dominan:

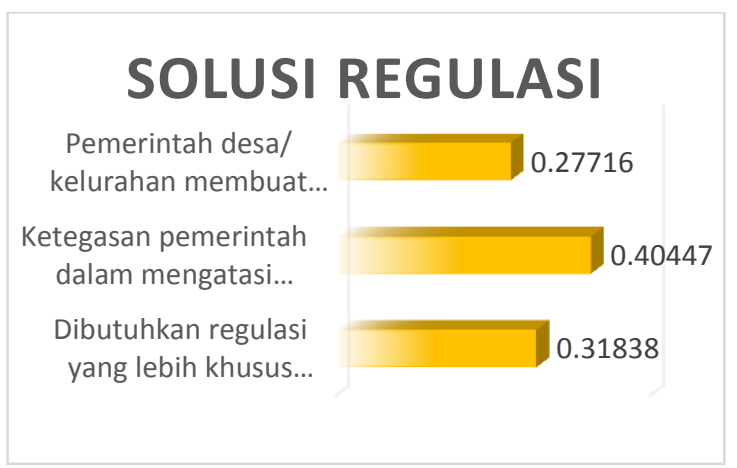

\section{Gambar 10. Solusi Regulasi}

Solusi yang paling dominan menurut responden adalah "ketegasan pemerintah dalam mengatasi maraknya rentenir termasuk sanksinya”. Pemerintah harus tegas mengatasi rentenir dan memberikan sanksi yang wajar, karena perilaku para rentenir sudah meresahkan masyarakat bahkan tidak sedikit masyarakat yang kehilangan harta bendanya karena terlilit hutang rentenir. Buat aturan yang lebih spesifik agar tindakan "perlawanan" terhadap rentinir yang dilakukan oleh aparat yang berwenang tidak menyalahi aturan. Solusi kedua adalah "dibutuhkan regulasi yang lebih khusus mengenai BMT seperti perbankan”. Aturan BMT yang sama dengan perbankan, akan membuat langkah BMT semakin leluasa, seperti koneksi 
yang terhubung dengan sistem IT antar BMT, memungkinkan BMT bisa lebih berkembang melakukan kerjasama antar BMT sehingga dapat sharing informasi dan yang lainnya. Solusi terakhir dari solusi regulasi adalah "Pemerintah desa/ kelurahan membuat aturan mengenai larangan rentenir”. Ketika aturan secara tertulis dari pemerintah pusat sudah jelas mengenai penyelesaian rentenir, maka pemerintah daerah akan lebih memiliki dasar kebijakan dalam mengatasi masalah rentenir dilapangan, sehingga penegakan hukum akan lebih adil dan tidak menimbulkan kekisruhan antar kepentingan baik itu rentenirnya atau masyarakat yang terjerat rentenir. hal ini tentunya harus harus disinergikan dengan masyarakat RT, RW serta masyarakat setempat. Nilai rater agreement yaitu sebesar $\mathrm{W}=0,613$ atau $61,3 \%$ yang artinya menunjukkan kesepakatan yang tinggi diantara responden dalam menjawab solusi regulasi

\section{Simpulan}

Masalah-masalah rentenir yang dapat menyebabkan terhambatnya pelaksanaan fungsi BMT diantaranya: a) masalah edukasi yaitu "lemahnya edukasi mengenai riba (fiqh riba)", "Lemahnya pendidikan formal masyarakat terutama mengenai manajemen keuangan (usaha dan ekonomi rumah tangga)", dan "Minimnya peran serta lembaga pendidikan dalam melakukan edukasi mengenai lembaga mikro kepada masyarakat", b) masalah ekonomi yaitu: "Kebutuhan hidup masyarakat yang mendesak", Ketersediaan dana di BMT tidak cukup", Masalah kebijakan ekonomi pemerintah yang tidak pro rakyat kecil", dan "Produk BMT yang kurang inovatif”, c) masalah lingkungan yaitu: "Kantor BMT biasanya kecil bahkan tidak dikenal masyarakat", "Ketertarikan / ikut-ikutan dengan lingkungan sekitar (pengaruh tetangga)", "Sangat mudah mengakses rentenir", dan "Tidak ada sumber informasi mengenai BMT", d) masalah regulasi d) masalah regulasi yaitu: "Lemahnya penerapan sanksi mengenai masyarakat yang melakukan penghimpunan dana dari masyarakat karena sulitnya melakukan identifikasi kasusu yang harus menunggu laporan dari masyarakat", "Regulasi/ payung hukum BMT tidak terlalu spesifik seperti perbankan”, “Tidak ada ketegasan pemerintah terhadap rentenir"

Solusi-solusi untuk mengembalikan fungsi BMT melalui strategi penyelesain rentenir diantaranya: a) solusi edukasi yaitu: "Adanya pelatihan manajemen usaha dan ekonomi rumah tangga pada masyarakat", "Adanya pusat pendidikan, konsultasi usaha mikro bagi 
UKM/UMKM: pengelolaan keuangan" dan "Sosialisasi oleh akademisi dan majelis ta`lim mengenai pentingnya BMT, fiqh riba". b) solusi ekonomi yaitu: "Bantuan dana bergulir dari pemerintah non bunga yang tidak berbelit-belit", "Kebijakan Ekonomi pemerintah yang berpihak pada masyarakat kecil", "Kerjasama usaha dengan pihak yang telah sukses", dan "Produk BMT lebih bervariasi mengikuti kebutuhan pasar, dengan tingkat margin/ bagi hasil yang bersaing". c) solusi lingkungan yaitu: "Menciptakan/ rekayasa lingkungan Islami", "Peran serta ketua RT dan RW untuk memberantas rentenir", dan "Perbanyak program pengabdian pada masyarakat dari akademisi terkait kesadaran lingkungan mengenai bahaya riba". d) solusi regulasi yaitu: "Dibutuhkan regulasi yang lebih khusus mengenai BMT seperti perbankan", "Ketegasan pemerintah dalam mengatasi maraknya rentenir termasuk sanksinya", dan "Pemerintah desa/ kelurahan membuat aturan mengenai larangan rentenir”.

\section{Bibliograpy}

Ascarya. (2005). Analytic Network Process (ANP): Pendekatan Baru Studi Kualitatif. Pusat Pendidikan dan Studi Kebanksentralan. Bank Indonesia.
Ascarya. (2011). The Persistence of Low Profit and Loss Sharing Financing in Islamic Banking: The Case of Indonesia. Review of Indonesian economic and business studies. LIPI Economic Research Center, 1. Ascarya \& Yumanita, D. (2010). Determinan dan Persistensi Margin Perbankan Konvensional dan Syariah di Indonesia. working paper series No.WP/10/04. Pusat Pendidikan dan Studi Kebanksentralan Bank Indonesia.

Firmansyah, H.M. (2019). Rentenir Berkedok Koperasi Marak di Tasikmalaya.

Htpps://mediadesa.id/rentenirberkedok-koperasi-marak-ditasikmalaya/

Hidayah, Naning Nur. (2018). Infaq Sebagai Program Pengurangan Ketergantungan Masyarakat Terhadap Rentenir (Studi Kasus Pada Baznas Kabupaten Ngawi). Skripsi. UIN Sunan Kalijaga. Jogjakarta

Huda, Nurul \& Muhammad Haykal. (2010) Lembaga Keuangan Islam. Jakarta: Kencana Prenada Media Grup.

Kabar Priangan. (2018) .Pedagang Kecil dan Ibu Rumah Tangga Banyak Terbelit

Rentenir. 
https://www.kabarpriangan.co.id/p

edagang-kecil-dan-ibu-rumah-

tangga-banyak-terbelit-rentenir/

Mujaddidi, Ahmad Shibghatullah. (2017).

Peran Strategis BAyt Al-Mal Wa Al-Tamwil Dalam Mengatasi Prektek Rentenir : Studi BMT NU Jawa Timur. Tesis. Sekolah Pascasarjana UIN Syarif Hidayatullah. Jakarta.

Nurjamil, Nanang. (2018). Disinyalir Praktek Rentenir Makin Menjamur di Kota Tasik. http://www.tasikzone.com/disinyali r-praktek-rentenir-makinmenjamur-di-kota-tasik/

Ramadhan, Syahrul. (2017). Pengorganisasian Ibu-Ibu Jamaah Aisyiyah Dalam Pengentasan Masyarakat dari Belenggu Rentenir di Kelurahan Kalijudan Surabaya. Jurnal Tajdida. Vol. 15 No. 1, Juni 2017

Ridwan, Ahmad Hasan. (2013). Manajemen Baitul Mal wa Tamwil. Pustaka Setia. Bandung.

Soemitra, Andri. (2014). Bank dan Lembaga Keuangan Syariah. Jakarta: Kencana . (2010). Bank dan Lembaga Keuangan Syariah. Jakarta: Kencana Varghese, Adel. (2013). CooperativeMoneylender Linkkage as an
Alternativer to Bank Competition in Rural Credit Markets. Source: Oxford Economic Papers, 57 (2). Published by: Oxford University Press Stable.

Widodo, Hertanto Ak, dkk. (2000). Panduan Praktis Operasional Baitul Mal Wat Tamwil (BMT), (Bandung: Mizan, 2000), Cet ke-2 